\title{
Unifying Children's Surgery and Anesthesia Stakeholders Across Institutions and Clinical Disciplines: Challenges and Solutions from Uganda
}

\author{
Phyllis Kisa $^{1} \cdot$ David F. Grabski $^{2} \cdot$ Doruk Ozgediz $^{3} \cdot$ Margaret Ajiko $^{4} \cdot$ Raffaele Aspide $^{5} \cdot$ \\ Robert Baird ${ }^{6}$ - Gillian Barker ${ }^{7}$ - Doreen Birabwa-Male ${ }^{8}$ - Geoffrey Blair ${ }^{6}$. \\ Brian Cameron ${ }^{9} \cdot$ Maija Cheung ${ }^{3}$ - Bruno Cigliano ${ }^{5}$ - David Cunningham ${ }^{10}$. \\ Sergio D'Agostino ${ }^{5}$ - Damian Duffy ${ }^{6}$ - Faye Evans ${ }^{11}$ - Tamara N. Fitzgerald ${ }^{12}$. \\ George Galiwango $^{13}$ - Domenico Gerolmini ${ }^{5}$ - Marcello Gerolmini ${ }^{5} \cdot$ Nasser Kakembo $^{1}$. \\ Joyce B. Kambugu ${ }^{14}$ - Kokila Lakhoo ${ }^{15}$ - Monica Langer ${ }^{16}$ - Moses Fisha Muhumuza ${ }^{13}$. \\ Arlene Muzira $^{1} \cdot$ Mary T. Nabukenya $^{17} \cdot$ Bindi Naik-Mathuria $^{18} \cdot$ Doreen Nakku $^{19}$. $^{13}$ \\ Jolly Nankunda $^{20} \cdot$ Martin Ogwang $^{21} \cdot$ Innocent Okello $^{1} \cdot$ Norgrove Penny $^{22}$. \\ Eleanor Reimer $^{23} \cdot$ Coleen Sabatini $^{24} \cdot$ John Sekabira ${ }^{1}$ - Martin Situma ${ }^{19}$. \\ Peter Ssenyonga $^{25} \cdot$ Janat Tumukunde $^{17}$ - Gustavo Villalona ${ }^{26}$
}

Published online: 7 January 2019

(C) Société Internationale de Chirurgie 2019

\begin{abstract}
Background There is a significant unmet need for children's surgical care in low- and middle-income countries (LMICs). Multidisciplinary collaboration is required to advance the surgical and anesthesia care of children's surgical conditions such as congenital conditions, cancer and injuries. Nonetheless, there are limited examples of this process from LMICs. We describe the development and 3-year outcomes following a 2015 stakeholders' meeting in Uganda to catalyze multidisciplinary and multi-institutional collaboration.

Methods The stakeholders' meeting was a daylong conference held in Kampala with local, regional and international collaborators in attendance. Multiple clinical specialties including surgical subspecialists, pediatric anesthesia, perioperative nursing, pediatric oncology and neonatology were represented. Key thematic areas including infrastructure, training and workforce retention, service delivery, and research and advocacy were addressed, and shortterm objectives were agreed upon. We reported the 3-year outcomes following the meeting by thematic area.

Results The Pediatric Surgical Foundation was developed following the meeting to formalize coordination between institutions. Through international collaborations, operating room capacity has increased. A pediatric general surgery fellowship has expanded at Mulago and Mbarara hospitals supplemented by an international fellowship in multiple disciplines. Coordinated outreach camps have continued to assist with training and service delivery in rural regional hospitals.

Conclusion Collaborations between disciplines, both within LMICs and with international partners, are required to advance children's surgery. The unification of stakeholders across clinical disciplines and institutional partnerships can facilitate increased children's surgical capacity. Such a process may prove useful in other LMICs with a wide range of children's surgery stakeholders.
\end{abstract}

Joint first authors: Phyllis Kisa and David F. Grabski.

Doruk Ozgediz

doruk.ozgediz@yale.edu

1 Department of Surgery, Makerere University School of Medicine, Kampala, Uganda
Department of Surgery, University of Virginia School of Medicine, Charlottesville, USA

3 Department of Surgery, Yale University School of Medicine, New Haven, USA 


\section{Introduction}

\section{Importance of unifying stakeholders across disciplines}

Recent studies have highlighted the substantial unmet need in global surgery and anesthesia care and the importance of children's surgical conditions [1-4]. The new global commitment to the Sustainable Development Goals and Universal Health Coverage in low- and middle-income countries (LMICs) requires collaborative solutions across clinical disciplines [4], high-income country (HIC) and LMIC partners [5] and implementation at different levels of the healthcare system [6].

Recent initiatives have highlighted the interdependence of clinical disciplines to address unmet global surgical needs. The World Health Organization has recently supported the development of National Surgical, Obstetric and Anesthesia Plans (NSOAPs) to improve surgical access [7-9]. The Global Alliance for Surgery, Obstetric, Trauma, and Anaesthesia Care (The G4 Alliance) was developed to unify stakeholders and strengthen surgical systems through consensus surgical indicators [10]. The Global Initiative for Children's Surgery (GICS) has proposed "Optimal Resources for Children's Surgery" in LMICs through multidisciplinary stakeholders [6].

At the national level, expansion of perioperative care to include anesthesia and nursing has had marked benefits in LMICs [11, 12]. Improved surgical outcomes have resulted

4 Soroti Regional Referral Hospital, Soroti, Uganda

5 Surgery for Children, Vicenza, Italy

6 Department of Surgery, University of British Columbia Faculty of Medicine, Vancouver, Canada

7 Department of Women's and Children's Health, Uppsala University, Uppsala, Sweden

8 Mulago National Referral Hospital, Uganda Ministry of Health, Kampala, Uganda

9 Department of Surgery, McMaster University Faculty of Health Sciences, Hamilton, Canada

10 KidsOR, Aberdeen, Scotland

11 Department of Anesthesiology, Harvard Medical School, Boston, USA

12 Department of Surgery, Duke University School of Medicine, Durham, USA

13 CORSU Rehabilitation Hospital, Kisubi, Uganda

14 Uganda Cancer Institute, Kampala, Uganda

15 Department of Paediatric Surgery, Oxford University, Oxford, UK

16 Department of Surgery, Northwestern University School of Medicine, Chicago, USA from partnership with pediatric oncology, neonatology and community health-worker networks in LMICs. Standardizing chemotherapy protocols in LMICs have demonstrated benefits in children with cancer [13], though investigations remain limited to selected diseases and institutions. Multidisciplinary care following neonatal surgery in Nigeria was associated with improved postoperative mortality [14]. The integration of pediatric trauma care with injury prevention networks in LMICs has recently grown [15]. Specialty hospitals utilizing the principles of communitybased rehabilitation have greatly expanded club-foot care globally [16] and have scaled up both service delivery and training of orthopedic surgeons in LMICs [17].

\section{Children's surgical care in Uganda}

Children's surgical care in Uganda in 2015 was similar to many LMICs, with significant limitations in surgical capacity and substantial unmet need [18-22]. The government sector had insufficient resources to match the demands of a pediatric population of over 20 million children [2]. Two clinically based Ugandan pediatric general surgeons served a population estimated to require 200 pediatric surgeons [23]. Furthermore, training in pediatric anesthesia and children's surgical subspecialties was almost completely absent [24, 25]. Large infrastructure gaps in the public sector limited care, with one dedicated pediatric general surgery unit, one neonatal intensive care unit (NICU) without ventilators and one pediatric intensive

17 Department of Anesthesiology, Makerere University School of Medicine, Kampala, Uganda

18 Department of Surgery, Baylor College of Medicine, Houston, USA

19 Department of Surgery, Mbarara University of Science and Technology Faculty of Medicine, Mbarara, Uganda

20 Department of Paediatrics and Child Health, Makerere University School of Medicine, Kampala, Uganda

21 St. Mary's Lacor Hospital, Gulu, Uganda

22 Department of Orthopedics, University of British Columbia Faculty of Medicine, Vancouver, Canada

23 Department of Anesthesiology, University of British Columbia Faculty of Medicine, Vancouver, Canada

24 Department of Orthopedic Surgery, University of California San Francisco, San Francisco, USA

25 CURE Children's Hospital of Uganda, Mbale, Uganda

26 Department of Surgery, Saint Louis University School of Medicine, St. Louis, USA 
care unit (PICU) in the country, all located in the capital city. There was also no national referral system between different levels of the healthcare system including specialty hospitals.

The result was multiple, local and international groups individually confronting these challenges without a forum to communicate program aims, challenges and lessons learned. For example, clinical and surgical training programs were beginning to develop between local partners and international collaborators, but remained isolated between specific institutions. This fragmented health system for children's surgery led a small group of Ugandan and international pediatric general surgeons and anesthesiologists to organize a stakeholder's meeting to directly address the gap in coordination and collaboration between institutions involved in the surgical care of children within the country.

\section{Stakeholders' meeting}

The 1-day stakeholders' meeting, which followed a Uganda national surgical collaborators' conference, was held in Kampala, Uganda, in September 2015 [26]. Multiple long-standing personal and organizational relationships composing an unofficial children's surgery network facilitated the meeting. A wide range of stakeholders were represented (Table 1).

The meeting initially established the challenges and unmet needs facing children's surgery in Uganda. Selected concerns included a lack of care coordination for complex surgical disease such as congenital malformations and cancer. The need for dedicated children's operating rooms, increased critical care resources and increased capacity of regional hospitals to perform children's surgery were also emphasized. Additional sessions highlighted surgical subspecialties, anesthesia, nursing, nutrition and current work in research, policy and child health.

Breakout groups then addressed four key thematic areas: infrastructure, training and workforce retention, service delivery, and research and advocacy. Specific short- and medium-term action plans were developed. These included the creation of a foundation for children's surgery in Uganda to help coordinate children's surgical care. Other short-term objectives included:

1. Expanding surgical outreach camps for local pediatric surgical groups to rural hospitals and continued presence of international organizations providing service delivery;

2. Promoting a hybrid training model with both incountry children's surgery training complemented by international HIC training as needed and increased training opportunities for care providers in rural hospitals;

3. Increasing research capacity including defining surgical need, congenital anomaly burden, pediatric injury research and

4. Increasing infrastructure for children's surgery operating rooms and neonatal and pediatric intensive care wards.

\section{Components critical to success of stakeholders' meeting}

The strength of the stakeholder's meeting was the broad representation from diverse medical and surgical disciplines from various levels of the health system in Uganda. Furthermore, representation included both local and international partners from academic institutions, faith-based collaborators and other non-governmental organizations (NGOs). The meeting built on previously established relationships and existing in-country networks to bridge clinical and institutional divisions. Other key aspects to this process were: 1 . The stakeholders' meeting was a Ugandan-led initiative; 2 . there was a shared vision to improve surgical care for children in the absence of personal or institutional agendas; 3. most of the NGOs invested in children's surgery and represented at the meeting had 10-20 years of engagement in Uganda; and 4. crosscutting clinical areas such as pediatric anesthesia and perioperative care, neonatology, oncology and nursing were emphasized.

\section{Three-year outcomes following the stakeholders' meeting by thematic area}

Given the importance of clinical collaboration in global children's surgery and anesthesia but with sparse evidence evaluating this process in LMICs, we reviewed our 3-year outcomes following the stakeholders' meeting. Through progress reports and in-person interviews, we analyze the impact on quality and capacity of children's surgery in Uganda by thematic areas: infrastructure, service delivery, training (including subspecialties) and research.

\section{Infrastructure}

Insufficient children's surgery, anesthesia and pediatric intensive care infrastructure was a key impediment to service delivery, especially in rural hospitals. Following the stakeholders' meeting in 2015, there has been a significant increase in the number of dedicated pediatric operating rooms in Uganda, initially through the work of 
Table 1 Key organizations represented at stakeholder's meeting or developed subsequently

\begin{tabular}{|c|c|c|c|c|c|}
\hline Organization & Nationality & $\begin{array}{l}\text { Predominate } \\
\text { thematic area }\end{array}$ & Clinical specialty & Successes & Challenges faced \\
\hline $\begin{array}{l}\text { Mulago } \\
\text { Hospital }\end{array}$ & Uganda & $\begin{array}{l}\text { Service } \\
\text { delivery, } \\
\text { training, } \\
\text { research }\end{array}$ & $\begin{array}{l}\text { Pediatric general surgery, } \\
\text { anesthesia, NICU, } \\
\text { oncology, nursing, } \\
\text { nutritionists }\end{array}$ & $\begin{array}{l}\text { Outreach camps to rural } \\
\text { hospitals } \\
\text { COSECSA pediatric surgical } \\
\text { training site } \\
\text { Pediatric anesthesia training } \\
\text { site }\end{array}$ & $\begin{array}{l}\text { Poor referral system } \\
\text { Insufficient capacity for } \\
\text { children's surgery } \\
\text { Large infrastructure/ } \\
\text { resource consumption } \\
\text { More focus on nursing } \\
\text { training }\end{array}$ \\
\hline $\begin{array}{l}\text { Mbarara } \\
\text { Hospital }\end{array}$ & Uganda & $\begin{array}{l}\text { Service } \\
\text { delivery, } \\
\text { training, } \\
\text { research }\end{array}$ & Pediatric general surgery & $\begin{array}{l}\text { COSECSA training site } \\
\text { Increase surgical capacity } \\
\text { Archie/KidsOR dedicated } \\
\text { operating space }\end{array}$ & Lack of pediatric ICU \\
\hline Soroti Hospital & Uganda & $\begin{array}{l}\text { Service } \\
\text { delivery }\end{array}$ & General surgery & $\begin{array}{l}\text { Service delivery in rural } \\
\text { regional hospital } \\
\text { Intern training } \\
\text { Scholarly work }\end{array}$ & $\begin{array}{l}\text { Lack of subspecialties } \\
\text { ICU capacity } \\
\text { Infrastructure } \\
\text { Consumables }\end{array}$ \\
\hline $\begin{array}{l}\text { St. Mary's } \\
\text { Lacor } \\
\text { Hospital }\end{array}$ & Uganda & $\begin{array}{l}\text { Service } \\
\text { delivery }\end{array}$ & $\begin{array}{l}\text { General surgery, pediatric } \\
\text { general surgery }\end{array}$ & $\begin{array}{l}\text { Service delivery in rural } \\
\text { regional hospital }\end{array}$ & $\begin{array}{l}\text { Lack of subspecialties } \\
\text { ICU capacity }\end{array}$ \\
\hline KidsOR & Scotland & Infrastructure & $\begin{array}{l}\text { Non-governmental } \\
\text { organization }\end{array}$ & $\begin{array}{l}\text { Fully equip pediatric operating } \\
\text { rooms ( } 2 \text { built, } 3 \text { under } \\
\text { development) }\end{array}$ & $\begin{array}{l}\text { Maintenance, repair and } \\
\text { replacement of invested } \\
\text { equipment } \\
\text { Lack of local biomed } \\
\text { personnel }\end{array}$ \\
\hline CoRSU & Uganda & $\begin{array}{l}\text { Service } \\
\quad \text { delivery, } \\
\text { training }\end{array}$ & $\begin{array}{l}\text { Pediatric, orthopedic and } \\
\text { plastic surgery }\end{array}$ & $\begin{array}{l}5000 \text { pediatric reconstructive } \\
\text { cases/year including cleft } \\
\text { lip/palate and limb salvage } \\
\text { Specialist training in pediatric } \\
\text { orthopedics and plastic } \\
\text { surgery } \\
\text { Community-based } \\
\text { rehabilitation programs } \\
\text { Scale-up of club-foot training }\end{array}$ & $\begin{array}{l}\text { Expanding training } \\
\text { program for pediatric } \\
\text { subspecialty programs } \\
\text { Harmonizing with public } \\
\text { sector } \\
\text { Scaling up crosscutting } \\
\text { programs }\end{array}$ \\
\hline $\begin{array}{l}\text { CURE } \\
\text { Hospital }\end{array}$ & Uganda & $\begin{array}{l}\text { Service } \\
\text { delivery, } \\
\text { training }\end{array}$ & Pediatric neurosurgery & $\begin{array}{l}\text { Subspecialty care in regional } \\
\text { hospital }\end{array}$ & $\begin{array}{l}\text { Harmonizing with public } \\
\text { sector }\end{array}$ \\
\hline GPAS & $\begin{array}{l}\text { Uganda } \\
\text { International } \\
\text { Partners }\end{array}$ & Training & $\begin{array}{l}\text { Pediatric general surgery, } \\
\text { pediatric anesthesia }\end{array}$ & $\begin{array}{l}\text { Training and workforce } \\
\text { expansion }\end{array}$ & $\begin{array}{l}\text { Sustainable funding, } \\
\text { advocacy }\end{array}$ \\
\hline $\begin{array}{l}\text { Uganda } \\
\text { Paediatric } \\
\text { Association }\end{array}$ & Uganda & $\begin{array}{l}\text { Training, } \\
\quad \text { advocacy }\end{array}$ & $\begin{array}{l}\text { Multiple clinical pediatric } \\
\text { subspecialties }\end{array}$ & $\begin{array}{l}\text { Advocacy, collaboration } \\
\text { between pediatric } \\
\text { specialities }\end{array}$ & Integration of specialties \\
\hline $\begin{array}{l}\text { Uganda } \\
\text { training } \\
\text { alliance }\end{array}$ & $\begin{array}{l}\text { Uganda- } \\
\text { Canada }\end{array}$ & Training & $\begin{array}{l}\text { Pediatric general surgery, } \\
\text { pediatric anesthesia }\end{array}$ & $\begin{array}{l}\text { International pediatric surgery, } \\
\text { anesthesia, urology } \\
\text { fellowship }\end{array}$ & $\begin{array}{l}\text { Expansion of program to } \\
\text { other disciplines } \\
\text { Sustainability }\end{array}$ \\
\hline $\begin{array}{l}\text { Surgery for } \\
\text { children }\end{array}$ & Uganda-Italy & $\begin{array}{l}\text { Service } \\
\quad \text { delivery, } \\
\text { training }\end{array}$ & $\begin{array}{l}\text { Pediatric general surgery, } \\
\text { pediatric anesthesia, } \\
\text { pediatric urology }\end{array}$ & $\begin{array}{l}\text { Service delivery in rural } \\
\text { regional hospital } \\
\text { Concentration on anorectal } \\
\text { and urogenital anomalies } \\
\text { Training local surgeons and } \\
\text { anesthesia providers } \\
\text { Inspiring young surgeons } \\
\text { toward children's surgery } \\
\text { careers }\end{array}$ & $\begin{array}{l}\text { Sustainability } \\
\text { Long-term goals }\end{array}$ \\
\hline
\end{tabular}


Table 1 continued

\begin{tabular}{|c|c|c|c|c|c|}
\hline Organization & Nationality & $\begin{array}{l}\text { Predominate } \\
\text { thematic area }\end{array}$ & Clinical specialty & Successes & Challenges faced \\
\hline $\begin{array}{l}\text { Pediatric } \\
\text { urology } \\
\text { collaboration }\end{array}$ & $\begin{array}{l}\text { Uganda- } \\
\text { Uppsala }\end{array}$ & $\begin{array}{l}\text { Training, } \\
\text { service } \\
\text { delivery }\end{array}$ & Pediatric urology & $\begin{array}{l}\text { Training in pediatric urology } \\
\text { Bilateral exchange/teaching } \\
\text { Establishment of DSD clinic }\end{array}$ & $\begin{array}{l}\text { Expansion of training and } \\
\text { clinical programs } \\
\text { Sustainability }\end{array}$ \\
\hline $\begin{array}{l}\text { Surgical } \\
\text { oncology } \\
\text { collaboration }\end{array}$ & $\begin{array}{l}\text { Baylor-Uganda } \\
\text { Cancer } \\
\text { Institute }\end{array}$ & $\begin{array}{l}\text { Training, } \\
\text { service } \\
\text { delivery, } \\
\text { research }\end{array}$ & $\begin{array}{l}\text { Pediatric general surgery, } \\
\text { anesthesia, perioperative } \\
\text { nursing }\end{array}$ & $\begin{array}{l}\text { Capacity building for medical } \\
\text { and surgical oncology } \\
\text { International observerships in } \\
\text { pediatric surgical oncology }\end{array}$ & $\begin{array}{l}\text { Integration with existing } \\
\text { programs } \\
\text { Support for specialized } \\
\text { areas of pediatric surgery }\end{array}$ \\
\hline $\begin{array}{l}\text { McMaster } \\
\text { University }\end{array}$ & Canadian & $\begin{array}{l}\text { Training, } \\
\quad \text { research }\end{array}$ & Pediatric general surgery & $\begin{array}{l}\text { Implemented Trauma Registry } \\
\text { in Mbarara }\end{array}$ & $\begin{array}{l}\text { Collaborations with } \\
\text { existing partners } \\
\text { Patient registration system }\end{array}$ \\
\hline $\begin{array}{l}\text { Oxford } \\
\text { University }\end{array}$ & UK & $\begin{array}{l}\text { Training, } \\
\quad \text { research }\end{array}$ & Pediatric general surgery & $\begin{array}{l}\text { Support for fellowship training } \\
\text { program }\end{array}$ & $\begin{array}{l}\text { Monitoring capacity } \\
\text { building, local } \\
\text { leadership, and program } \\
\text { development }\end{array}$ \\
\hline
\end{tabular}

Additional Organizations Represented at Meeting: Makerere University-Johns Hopkins University Research Collaboration, Archie Foundation, Baby Watoto Orphanage, Mbarara University of Science and Technology, St. Joseph's International Outreach Program

COSECSA College of Surgeons of East, Central, and Southern Africa, ICU intensive care unit, CoRSU Comprehensive Rehabilitation Services of Uganda, GPAS Global Partners in Anesthesia and Surgery, DSD disorders of sexual differentiation

the ARCHIE Foundation, a UK-based Charity, and now with the ongoing development of the service by Kids Operating Room (KidsOR), a UK-based NGO.

The first dedicated pediatric operating room in Uganda opened in the China-Uganda Friendship Hospital at Naguru, Kampala, in April 2015. Through the stakeholders' meeting, relationships were established with other pediatric surgeons in Uganda, and in November 2016, a second pediatric operating room was opened in Mbarara
(Fig. 1). The location of the second unit was influenced by the presence of a qualified pediatric surgeon, locally identified priorities and potential for training opportunities. An assessment of further expanded operating room capacity was carried out in January 2018, in parallel with plans for three dedicated pediatric operating rooms in the refurbished Mulago Hospital in Kampala, which is scheduled to be completed in early 2019. Further collaborations
Fig. 1 KidsOR operating theater in Mbarara, Uganda

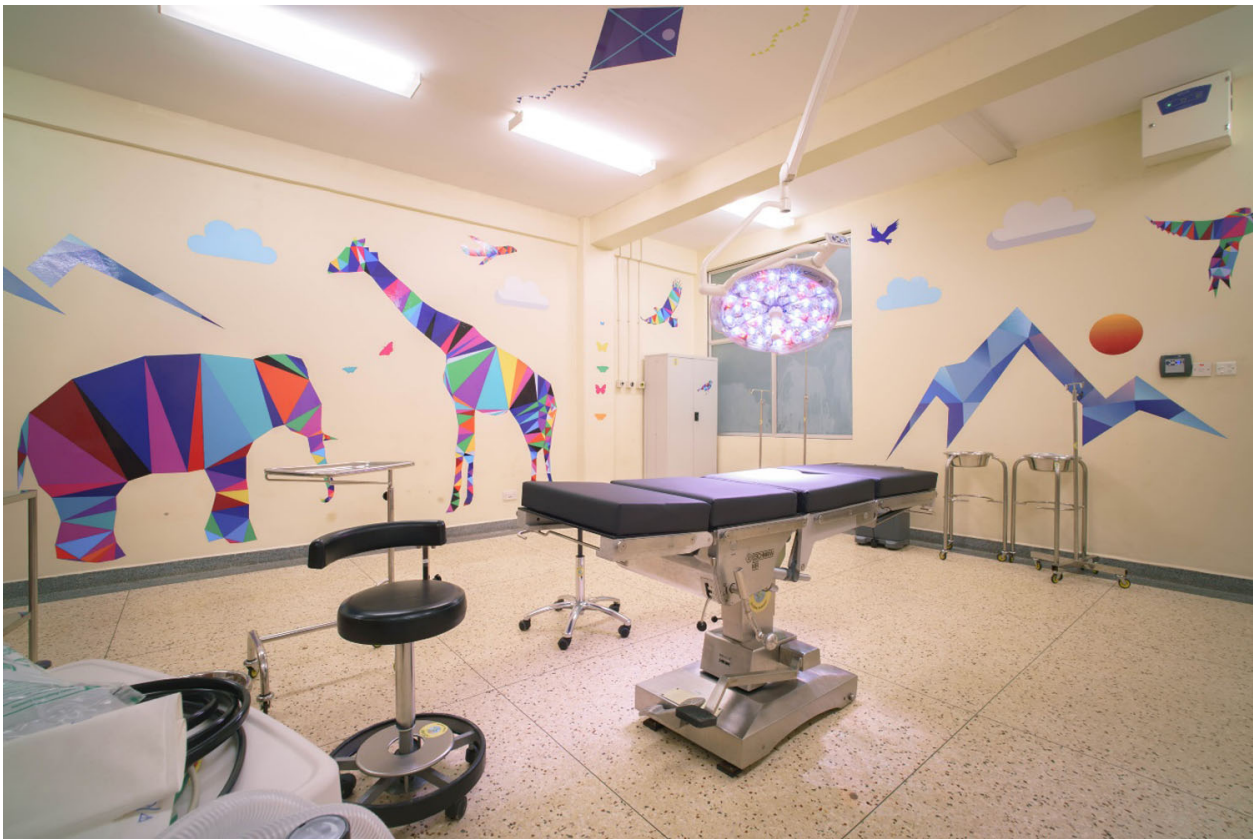


between KidsOR and other hospitals in Uganda are ongoing.

\section{Service delivery}

One of the highlighted deficiencies in surgical service delivery was a lack of coordinated care between specialty hospitals and the public sector. This led to the creation of the Pediatric Surgical Foundation, a Ugandan organization open to individual and organizational membership. The foundation has been officially recognized by the Ugandan government and is intended to help coordinate a formal network for both local and international groups caring for children with surgical needs. The foundation may also allow for central coordination with the Ugandan Ministry of Health.

In order to address the significant backlog of elective cases and poor surgical access in rural areas of Uganda, stakeholders supported the continued coordination and standardization of short-term surgical outreach missions or surgical camps. Surgical camps include both Uganda-led surgical outreach missions (usually 1-2 weeks) to district or regional hospitals in rural areas of the country and shortterm missions from international partners. Over the last 3 years, multiple outreach camps in pediatric general surgery, urology and surgical oncology have been conducted (Table 2). A majority of the cases have been elective definitive repairs of anorectal malformations, Hirschsprung's disease and urological conditions. The coordination of these camps has qualitatively increased since the stakeholders' meeting, with sharing of camp data, sitespecific strategies and ongoing challenges.

After the stakeholders' meeting in 2015, training and skill transfer to a wide range of providers remained an essential component of camps (Table 3). The camp forum facilitated hospital leaders and administrators' discussion of efficient methods of high-quality surgical care delivery. Local partnerships between Ugandan institutions have supported service delivery at the regional level, such as Mbarara Hospital, Masaka Hospital, St. Mary's Hospital Lacor and Soroti Hospital. Increased regional collaborations between Uganda hospitals and children's surgery teams have also occurred. One such collaboration between Mbarara and Fort Portal regional hospitals in western Uganda has developed to assist with complex elective pediatric surgery cases in the more rural center.

The need for resource guidelines to inform appropriate service delivery at various levels of the health system was emphasized at the meeting. This, in part, encouraged the development of the Optimal Resources document of GICS, which will require adaptation to the Uganda context [6].

\section{Training}

Stakeholders felt that increased specialty training was the most realistic solution to be addressed through collaboration. Local colleagues emphasized the impact of successful collaborations and capacity building on recruitment of young local surgeons and anesthesia providers-the leaders of the next generation. The stakeholders' meeting catalyzed the coordination of multiple independent training programs and allowed several institutional training relationships to grow and expand. With the expansion of the pediatric general surgery fellowship training in Uganda, four pediatric general surgery fellows have been trained over the last 3 years, more than doubling the number of pediatric surgeons. Mulago Hospital had been an official pediatric surgery training site through the College of Surgeons of East, Central, and Southern Africa (COSECSA), but fellows lacked funding, faculty was limited, and there were limited international training opportunities. Following the stakeholders' meeting, international collaborators began financially supporting in-country training of pediatric general surgery trainees as local sources of support were not available. Additionally, through the long-standing relationship between the pediatric surgery fellowship at Mulago and the Division of Pediatric Surgery at the University of British Columbia (UBC), UBC formed and funded a Ugandan fellowship for 1 year at Vancouver's British Columbia Children's Hospital. This fellowship was designed to supplement in-country training in Uganda with a competency-based curriculum as per the Royal College of Physicians and Surgeons of Canada (CanMEDS) competency domains [27]. The pediatric surgery fellowship has continued to develop with linkage between Mulago and Mbarara hospitals as a joint COSECSA training site, further increasing pediatric surgical training capacity. Additional international academic collaborations have led to extended international observerships for pediatric surgery fellows to supplement their exposure to pediatric intensive care training and laparoscopy.

This training model has expanded to include a UBCPediatric Anesthesia fellowship and Pediatric Urology fellowship. In addition, Inter-African partnership has increased pediatric anesthesia training in Uganda. Currently, the Anesthesia Department at Mulago has linked with the University of Nairobi and Red Cross War Memorial Children's Hospital (RCWMCH), sponsored by the World Federation of Societies of Anaesthesiologists (WFSA) and African Pediatric Fellowship Programme (APFP), to train an additional pediatric anesthesiologist who has since returned to practice in Uganda.

The Italian-based organization "Surgery for Children" has strengthened their long partnership with the surgical and anesthesia team at Lacor Regional Hospital and Gulu 


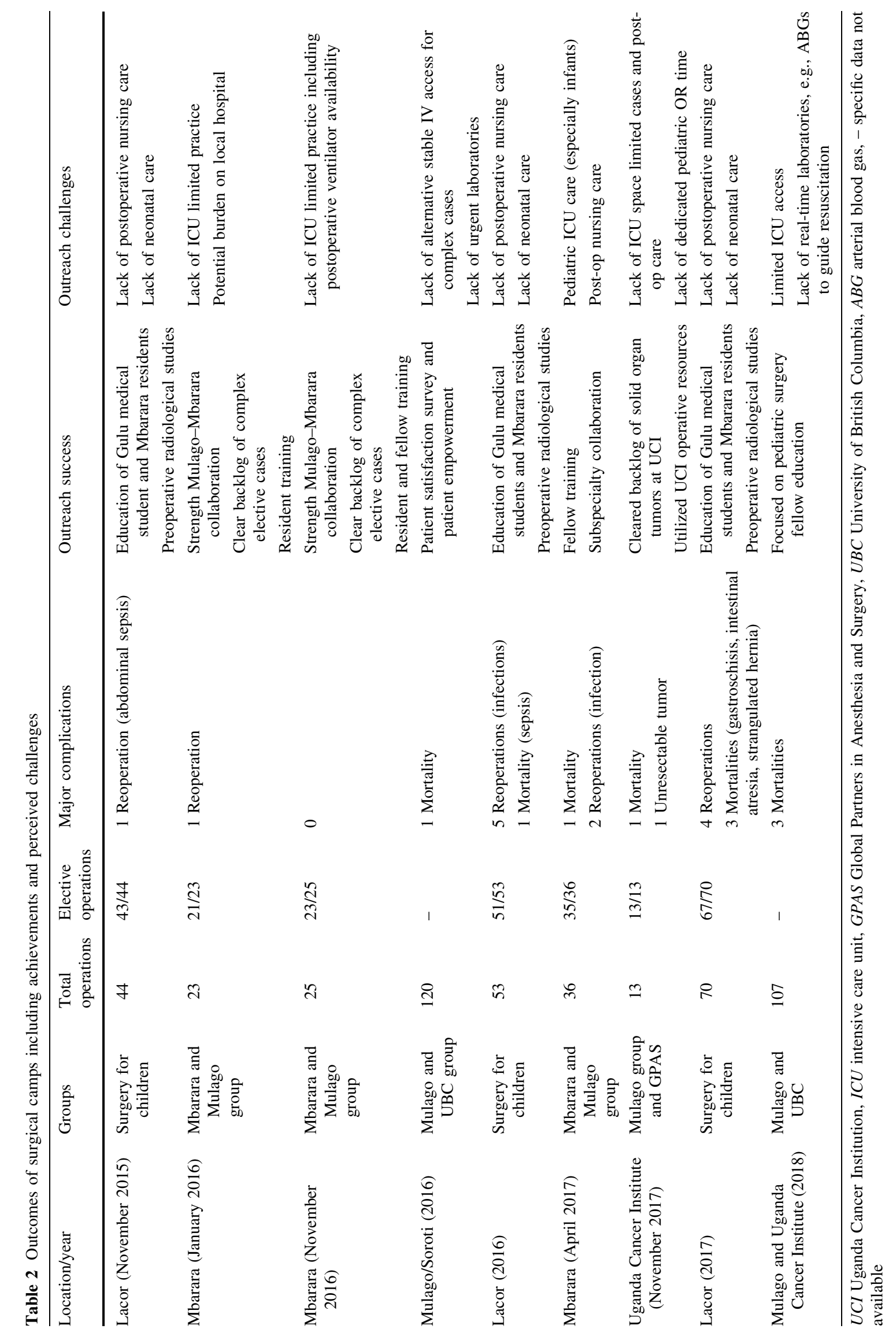


Table 3 Surgical and perioperative outreach teams involved in camps including trainees

\begin{tabular}{|c|c|c|c|c|c|c|c|c|c|}
\hline Location of camp & $\begin{array}{l}\text { Lacor } \\
\text { Nov } 2015\end{array}$ & $\begin{array}{l}\text { Mbarara } \\
\text { Jan } 2016\end{array}$ & $\begin{array}{l}\text { Mbarara } \\
\text { Nov } 2016\end{array}$ & $\begin{array}{l}\text { Mulago } \\
\text { and } \\
\text { Soroti } \\
2016\end{array}$ & $\begin{array}{l}\text { Lacor } \\
2016\end{array}$ & $\begin{array}{l}\text { Mbarara } \\
\text { April } \\
2017\end{array}$ & $\begin{array}{l}\text { UCI } \\
\text { Nov } 2017\end{array}$ & $\begin{array}{l}\text { Mulago } \\
\text { and UCI } \\
2018\end{array}$ & $\begin{array}{l}\text { Lacor } \\
2017\end{array}$ \\
\hline Institutions & $\begin{array}{l}\text { Surgery } \\
\text { for } \\
\text { children }\end{array}$ & $\begin{array}{l}\text { Mulago and } \\
\text { Mbarara } \\
\text { group }\end{array}$ & $\begin{array}{l}\text { Mulago and } \\
\text { Mbarara } \\
\text { group }\end{array}$ & UBC & $\begin{array}{l}\text { Surgery } \\
\text { for } \\
\text { children }\end{array}$ & Mulago & $\begin{array}{l}\text { GPAS and } \\
\text { Mulago } \\
\text { group }\end{array}$ & UBC & $\begin{array}{l}\text { Surgery } \\
\text { for } \\
\text { children }\end{array}$ \\
\hline Pediatric general & $1 \mathrm{UG}$ & $2 \mathrm{UG}$ & $3 \mathrm{UG}$ & 2 & 3 Italy & $2 \mathrm{US}$ & $2 \mathrm{UG}$ & 5 & $1 \mathrm{UG}$ \\
\hline surgeons & 1 Italy & $1 \mathrm{US}$ & $2 \mathrm{US}$ & & & $2 \mathrm{UG}$ & 3 US & & 4 Italy \\
\hline $\begin{array}{l}\text { Pediatric surgery } \\
\text { fellows }\end{array}$ & 0 & 0 & $1 \mathrm{UG}$ & 1 & 0 & $\begin{array}{l}2 \mathrm{UG} \\
1 \mathrm{US}\end{array}$ & $2 \mathrm{UG}$ & $3 \mathrm{UG}$ & 0 \\
\hline Surgery residents & $1 \mathrm{UG}$ & $2 \mathrm{UG}$ & $2 \mathrm{UG}$ & 2 & $1 \mathrm{UG}$ & $3 \mathrm{UG}$ & $\begin{array}{l}2 \mathrm{UG} \\
1 \mathrm{US}\end{array}$ & $3 \mathrm{UG}$ & $1 \mathrm{UG}$ \\
\hline Medical officers & $1 \mathrm{UG}$ & $2 \mathrm{UG}$ & $2 \mathrm{UG}$ & 3 & $1 \mathrm{UG}$ & 0 & $1 \mathrm{UG}$ & $1 \mathrm{UG}$ & $1 \mathrm{UG}$ \\
\hline Anesthesiologists & $\begin{array}{l}1 \mathrm{UG} \\
2 \text { Italy }\end{array}$ & $3 \mathrm{UG}$ & $3 \mathrm{UG}$ & 1 & $\begin{array}{l}1 \text { UG } \\
3 \text { Italy }\end{array}$ & $3 \mathrm{UG}$ & 0 & $\begin{array}{l}2 \mathrm{UG} \\
1 \mathrm{Can}\end{array}$ & $\begin{array}{l}1 \mathrm{UG} \\
3 \text { Italy }\end{array}$ \\
\hline $\begin{array}{r}\text { Anesthesia } \\
\text { residents }\end{array}$ & 0 & $4 \mathrm{UG}$ & $3 \mathrm{UG}$ & $5-7$ & & $3 \mathrm{UG}$ & 0 & $\begin{array}{l}4 \mathrm{UG} \\
1 \mathrm{Can}\end{array}$ & 1 Italy \\
\hline $\begin{array}{c}\text { Anesthesia } \\
\text { officers }\end{array}$ & $2 \mathrm{UG}$ & 0 & 0 & 2 & $2 \mathrm{UG}$ & $2 \mathrm{UG}$ & $3 \mathrm{UG}$ & 1 Can & $2 \mathrm{UG}$ \\
\hline
\end{tabular}

Can Canada, UCI Uganda Cancer Institute, UG Uganda, US United States, UBC University of British Colombia

University (Gulunap Project www.gulunap.unina.it). Their annual training and service trips to Lacor Hospital allow them to work closely with local staff to assist in training medical students, clinical officers, medical officers, anesthesia officers and operating room technicians. McMaster University and the St. Joseph's International Outreach Program have continued to support training in surgery, anesthesia and orthopedic surgery through clinical attachments in Canada as well as short-term visits of teams from Canada to perform skills-based workshops such as an orthopedic sawbones course, evidence-based medicine and laparoscopy. In addition, collaborations at CoRSU Rehabilitation Hospital have expanded local training opportunities in pediatric orthopedic and plastic surgery, both for trainees at CoRSU and in the public sector.

A substantial portion of children's surgical and anesthesia care continues to be provided by general surgeons, general doctors and anesthesia officers. As such, a training curriculum for general surgeons and medical officers in children's surgical emergencies has been developed and piloted in 2018 to a group of 13 rural providers with plans to scale up the course ("Appendix"). Similarly, the SAFE (Safer Anaesthesia from Education) Paediatric Anaesthesia Course developed by the Association of Anaesthetists of Great Britain and Ireland (AAGBI) and WFSA has been expanded over the last 3 years to anesthesia providers throughout the country. Lastly, a growing partnership with the Uganda Pediatric Association (UPA) has led to pediatric surgeons' involvement in the yearly UPA conferences, with presentations on surgical topics relevant to general pediatric providers.

\section{Children's subspecialties}

Unmet need and general backlog of elective cases in the public sector exist in the majority of the children's surgical specialties including orthopedic surgery, plastic surgery, neurosurgery, otolaryngology and urology [28, 29]. This has led to the formation of specialty hospitals within Uganda such as the Comprehensive Rehabilitation Services of Uganda (CoRSU) Hospital in Kisubi that specializes in pediatric orthopedic and plastic surgery reconstruction procedures. The hospital performs more than 5000 pediatric reconstruction cases each year through a network of rural partners that refer children to the hospital.

Despite a growing number of orthopedic surgeons within the country, an orthopedic surgery training program at Mulago Hospital and increasing interest in subspecialization, Uganda still does not have a pediatric orthopedic surgery fellowship. CoRSU does not have a formal academic partnership with Makerere University, despite close proximity, partially due to the constraints of University training requirements. Through the stakeholders' meeting, the paradigm of COSECSA training programs was discussed and remains a possible solution for pediatric orthopedic surgery training in Uganda. McMaster and UBC through the Uganda 
Sustainable Trauma and Orthopaedic Program (USTOP) program have also continued support of both in-country and international training [30]. For pediatric urology, a recent partnership with Uppsala, Sweden, has provided bilateral training opportunities and creation of a clinic to address children with disorders of sexual differentiation (DSD).

Multidisciplinary oncology care was highlighted at the stakeholders' meeting. Through the meeting and an ongoing pediatric solid organ tumor board, the pediatric oncology group at the Uganda Cancer Institute and the pediatric surgery and radiology teams at Mulago increased their clinical collaboration. The clinical collaboration with pediatric oncology and surgical oncology has also been strengthened through the Baylor Global HOPE (Hematology-Oncology Pediatric Excellence) program. This has led to a more integrated solid organ tumor board and pooled resources for infrastructure challenges. Nonetheless, 3 years following the stakeholders' meeting, limitations in operating time, anesthesia and intensive care resources constrain the ability to perform complex tumor resections within treatment protocol time frames.

\section{Research}

A major emphasis of the stakeholder's meeting was to better define the burden and unmet need of children's surgery. A prospective clinical database for pediatric general surgery used in Mulago Hospital was expanded to three other sites (Lacor, Soroti and Mbarara). This database has facilitated scholarly activity for Ugandan surgeons, surgery trainees and international partners. These have included pediatric surgical epidemiology and economic analysis, as well as disease-specific outcomes. Scholarly work across specialties has proliferated broadly and children's surgery research networks have grown along with clinical and training networks, which have expanded in the last 3 years (Table 4 ).

\section{Key accomplishments and lessons learned}

A stakeholders' meeting followed by purposeful collaboration can result in measurable deliverables in locally identified high-priority areas of infrastructure, training, service delivery and research. The alignment of stakeholders catalyzes collaboration across thematic areas. For example, aligning growth in pediatric surgery training and harmonization with infrastructure development has led to synergistic growth in service delivery. Small purposeful projects between different stakeholders can also strengthen links between different Ugandan institutions and clinical disciplines.
Over the last 3 years, in-country and international fellowship training opportunities have grown across multiple surgical specialties including anesthesia. Close collaboration with the NGO KidsOR has facilitated the development of multiple dedicated pediatric operating rooms in Uganda. The Ugandan experience has informed the expansion of KidsOR to a global scale. The consensus-building approach of stakeholders also strengthened the relationship between remote district and regional hospitals to national referral hospitals.

Additionally, collaboration with the Uganda Pediatric Association has led to children's surgery education programs for rural general providers and pediatricians to recognize and triage children's surgical disease including congenital anomalies. Though the impact of this collaboration is difficult to measure, the number of referrals from small district hospitals to regional hospitals like Mbarara appears to be increasing over the last 3 years. Lastly, building and maintaining relationships between local and international partners requires interdisciplinary collaborations, bilateral visits, shared authorship, opportunities for Ugandan providers to present at international conferences and joint priority setting.

\section{Remaining challenges to unify children's surgical stakeholders' in Uganda}

Numerous challenges remain to improve quality and capacity of children's surgery in Uganda. Critical care, radiology and pathology require additional specialtyspecific infrastructure. As infrastructure and service delivery develop, more complex surgical diseases pose new challenges. The coordination of complex surgical conditions including congenital anomalies and oncology continues to be fragmented among numerous specialties, hospitals and institutions. Despite the increase in pediatric general surgical training, subspecialty training in children's surgery including pediatric orthopedic, urology, neurosurgery and otolaryngology must be developed. In-country fellowship training programs for pediatric anesthesia and neonatology also need to be developed. A focus on nursing training in many of the collaborations is lacking and also must be addressed.

Increasing resource allocation for children's surgery from the Ministry of Health remains a key challenge as infrastructure development and workforce management ultimately depend on government financing. There continues to be limited jobs for newly trained providers specifically in the government sector, where the need is greatest. While surgical camps can help with elective backlogs, they are not sustainable solutions and cannot assist with emergencies or day-to-day challenges. There 
Table 4 Selected projects and outputs from research collaborations and prospective pediatric surgery database

\begin{tabular}{|c|c|c|c|c|c|c|}
\hline Year & Project theme & Output & Main findings & Action items & $\begin{array}{l}\text { Presenting } \\
\text { author }\end{array}$ & Senior author \\
\hline 2015 & $\begin{array}{l}\text { Patterns of burn care at } \\
\text { community health } \\
\text { centers in Uganda }\end{array}$ & $\begin{array}{l}\text { Oral presentation and } \\
\text { abstract publication }\end{array}$ & $\begin{array}{l}\text { Resource shortage in } \\
\text { community health } \\
\text { centers hinder burn } \\
\text { treatment }\end{array}$ & $\begin{array}{l}\text { Improve burn care } \\
\text { resources at health } \\
\text { community } \\
\text { facilities }\end{array}$ & $\begin{array}{l}\text { HIC } \\
\text { student }\end{array}$ & $\begin{array}{l}\text { LMIC pediatric } \\
\text { surgeon }\end{array}$ \\
\hline 2015 & $\begin{array}{l}\text { Household survey of } \\
\text { burn incidence in } \\
\text { Uganda }\end{array}$ & $\begin{array}{l}\text { Oral presentation and } \\
\text { abstract publication }\end{array}$ & $\begin{array}{l}\text { Incidence } 7: 1000 \text { people } \\
\text { Majority in children } \\
<4 \text { years old }\end{array}$ & $\begin{array}{l}\text { Findings to guide } \\
\text { future injury } \\
\text { prevention } \\
\text { campaigns }\end{array}$ & $\begin{array}{l}\text { HIC } \\
\text { medical } \\
\text { student }\end{array}$ & $\begin{array}{l}\text { LMIC pediatric } \\
\text { surgeon }\end{array}$ \\
\hline 2016 & $\begin{array}{l}\text { Clinical outcomes } \\
\text { following Wilms } \\
\text { tumor resection }\end{array}$ & Final thesis & $\begin{array}{l}\text { High rate of more } \\
\text { aggressive tumors }\end{array}$ & $\begin{array}{l}\text { Assess tumor } \\
\text { biology }\end{array}$ & $\begin{array}{l}\text { LMIC } \\
\text { trainee }\end{array}$ & $\begin{array}{l}\text { LMIC pediatric } \\
\text { surgeon }\end{array}$ \\
\hline 2016 & $\begin{array}{l}\text { Surgical outcomes } \\
\text { following } \\
\text { intussusception }\end{array}$ & Final thesis & $\begin{array}{l}20 \% \text { mortality } \\
\text { Radiographic reduction } \\
\text { not available }\end{array}$ & $\begin{array}{l}\text { Early diagnosis } \\
\text { Diversion in } \\
\text { unstable patients }\end{array}$ & $\begin{array}{l}\text { LMIC } \\
\text { trainee }\end{array}$ & $\begin{array}{l}\text { LMIC pediatric } \\
\text { surgeon }\end{array}$ \\
\hline 2016 & $\begin{array}{l}\text { Clinical burden of ileal } \\
\text { perforation from } \\
\text { typhoid disease }\end{array}$ & Final thesis & $20 \%$ mortality & $\begin{array}{l}\text { Prevention } \\
\text { Early diagnosis } \\
\text { Diversion in } \\
\text { unstable patients }\end{array}$ & $\begin{array}{l}\text { LMIC } \\
\text { trainee }\end{array}$ & $\begin{array}{l}\text { LMIC pediatric } \\
\text { surgeon }\end{array}$ \\
\hline 2016 & $\begin{array}{c}\text { Gastroschisis outcomes } \\
\text { in Mulago Hospital }\end{array}$ & Paper & $>90 \%$ mortality & $\begin{array}{l}\text { Early treatment and } \\
\text { reduction } \\
\text { Silo alternatives } \\
\text { TPN and nursing } \\
\text { care }\end{array}$ & $\begin{array}{l}\text { LMIC } \\
\text { trainee }\end{array}$ & $\begin{array}{l}\text { HIC/LMIC } \\
\text { pediatric } \\
\text { surgeon }\end{array}$ \\
\hline 2016 & $\begin{array}{c}\text { The role of physicians as } \\
\text { advocates for patient } \\
\text { care in rural Uganda }\end{array}$ & $\begin{array}{l}\text { Oral presentation and } \\
\text { abstract publication }\end{array}$ & $\begin{array}{l}\text { Physicians advocate on } \\
\text { personal level, } \\
\text { experience limitations }\end{array}$ & $\begin{array}{l}\text { Reduce barriers to } \\
\text { physician-guided } \\
\text { patient advocacy }\end{array}$ & $\begin{array}{l}\mathrm{HIC} \\
\text { student }\end{array}$ & $\begin{array}{l}\text { LMIC pediatric } \\
\text { surgeon }\end{array}$ \\
\hline 2016 & $\begin{array}{l}\text { Promotion of } \\
\text { collaboration and } \\
\text { priority setting for } \\
\text { children's surgery in } \\
\text { Uganda }\end{array}$ & $\begin{array}{l}\text { International } \\
\text { presentation }\end{array}$ & $\begin{array}{l}\text { Local stakeholder's } \\
\text { meetings and priority } \\
\text { setting can be useful }\end{array}$ & $\begin{array}{l}\text { Follow-up in } \\
\text { thematic areas and } \\
\text { assess progress }\end{array}$ & $\begin{array}{l}\text { LMIC } \\
\text { pediatric } \\
\text { surgeon }\end{array}$ & $\begin{array}{l}\text { LMIC pediatric } \\
\text { surgeon }\end{array}$ \\
\hline 2016 & $\begin{array}{l}\text { Role of rural outreach } \\
\text { camps on service } \\
\text { delivery of pediatric } \\
\text { surgery }\end{array}$ & $\begin{array}{l}\text { International } \\
\text { presentation }\end{array}$ & $\begin{array}{l}\text { Feasible and safe to } \\
\text { conduct camps }\end{array}$ & $\begin{array}{l}\text { Continue to assess } \\
\text { impact on burden } \\
\text { of disease and } \\
\text { skills transfer }\end{array}$ & $\begin{array}{l}\text { LMIC } \\
\text { pediatric } \\
\text { surgeon }\end{array}$ & $\begin{array}{l}\text { LMIC pediatric } \\
\text { surgeon }\end{array}$ \\
\hline 2016 & Diabetic foot amputation & $\begin{array}{l}\text { Oral presentation and } \\
\text { abstract publication }\end{array}$ & $\begin{array}{l}\text { Diabetic foot amputation } \\
\text { is common }\end{array}$ & $\begin{array}{l}\text { Implement early } \\
\text { diabetic screening } \\
\text { and treatment }\end{array}$ & $\begin{array}{l}\mathrm{HIC} \\
\text { student }\end{array}$ & $\begin{array}{l}\text { LMIC pediatric } \\
\text { surgeon }\end{array}$ \\
\hline 2016 & Social cost of ostomy & $\begin{array}{l}\text { International } \\
\text { presentation and } \\
\text { paper }\end{array}$ & $\begin{array}{l}\text { High rate of } \\
\text { socioeconomic burden } \\
\text { for families }\end{array}$ & $\begin{array}{l}\text { Family } \\
\text { support/counseling } \\
\text { Economic protection } \\
\text { Hiring nurse } \\
\text { coordinator for } \\
\text { colorectal program }\end{array}$ & $\begin{array}{l}\text { LMIC } \\
\text { pediatric } \\
\text { surgeon }\end{array}$ & $\begin{array}{l}\mathrm{LMIC} / \mathrm{HIC} \\
\text { pediatric } \\
\text { surgeon }\end{array}$ \\
\hline 2016 & $\begin{array}{l}\text { Epidemiology of } \\
\text { anorectal } \\
\text { malformations in } \\
\text { Uganda }\end{array}$ & Final thesis & $\begin{array}{l}\text { High rates of ARMs and } \\
\text { need for staged } \\
\text { procedures }\end{array}$ & Early diagnosis & $\begin{array}{l}\text { LMIC } \\
\text { trainee }\end{array}$ & $\begin{array}{l}\text { LMIC pediatric } \\
\text { surgeon }\end{array}$ \\
\hline 2016 & $\begin{array}{l}\text { Hand hygiene education } \\
\text { campaign at Soroti } \\
\text { Regional Referral } \\
\text { Hospital, Uganda }\end{array}$ & $\begin{array}{l}\text { Oral presentation and } \\
\text { abstract publication }\end{array}$ & $\begin{array}{l}\text { Low access to hand } \\
\text { hygiene measures } \\
\text { No prior assessment }\end{array}$ & $\begin{array}{l}\text { Implement education } \\
\text { campaign and } \\
\text { local infection } \\
\text { control }\end{array}$ & $\begin{array}{l}\text { HIC } \\
\text { medical } \\
\text { student }\end{array}$ & $\begin{array}{l}\text { LMIC pediatric } \\
\text { surgeon }\end{array}$ \\
\hline 2016 & $\begin{array}{l}\text { Understanding delays in } \\
\text { access to pediatric } \\
\text { surgical care }\end{array}$ & $\begin{array}{l}\text { Medical student } \\
\text { project }\end{array}$ & $\begin{array}{l}\text { Three delays all factor in } \\
\text { access }\end{array}$ & $\begin{array}{l}\text { Resources to reduce } \\
\text { three delays }\end{array}$ & $\begin{array}{l}\text { HIC } \\
\text { medical } \\
\text { student }\end{array}$ & $\begin{array}{r}\text { HIC/LMIC } \\
\text { pediatric } \\
\text { surgeons }\end{array}$ \\
\hline
\end{tabular}


Table 4 continued

\begin{tabular}{|c|c|c|c|c|c|c|}
\hline Year & Project theme & Output & Main findings & Action items & $\begin{array}{l}\text { Presenting } \\
\text { author }\end{array}$ & Senior author \\
\hline 2016 & $\begin{array}{l}\text { Developing pediatric } \\
\text { surgery in Uganda }\end{array}$ & $\begin{array}{l}\text { National presentation } \\
\text { (USA) }\end{array}$ & $\begin{array}{l}\text { High burden of disease } \\
\text { and limited human } \\
\text { resources }\end{array}$ & $\begin{array}{l}\text { Role of } \\
\text { collaborations to } \\
\text { develop capacity }\end{array}$ & $\begin{array}{l}\text { LMIC } \\
\text { pediatric } \\
\text { surgeon }\end{array}$ & $\begin{array}{l}\text { LMIC pediatric } \\
\text { surgeon }\end{array}$ \\
\hline 2016 & $\begin{array}{l}\text { Financial burden of } \\
\text { clinical investigation }\end{array}$ & $\begin{array}{l}\text { Oral presentation and } \\
\text { abstract publication }\end{array}$ & $\begin{array}{l}\text { Significant number of } \\
\text { patients experience } \\
\text { financial burden with } \\
\text { healthcare }\end{array}$ & $\begin{array}{l}\text { Develop financial } \\
\text { policies for } \\
\text { healthcare expense } \\
\text { protection }\end{array}$ & $\begin{array}{l}\text { HIC } \\
\text { student }\end{array}$ & $\begin{array}{l}\text { LMIC pediatric } \\
\text { surgeon }\end{array}$ \\
\hline 2016 & $\begin{array}{l}\text { Burden of pediatric } \\
\text { orthopedic disease in } \\
\text { Uganda }\end{array}$ & Collaborative project & $\begin{array}{l}\text { High burden of } \\
\text { musculoskeletal } \\
\text { disease }\end{array}$ & $\begin{array}{l}\text { Prevention and early } \\
\text { care programs }\end{array}$ & $\begin{array}{l}\text { HIC } \\
\text { medical } \\
\text { student }\end{array}$ & $\begin{array}{l}\text { HIC/LMIC } \\
\text { orthopedic } \\
\text { surgeons }\end{array}$ \\
\hline 2016 & $\begin{array}{l}\text { Gluteal fibrosis and } \\
\text { sciatic nerve injury } \\
\text { from injections }\end{array}$ & Collaborative project & $\begin{array}{l}\text { Substantial burden of } \\
\text { gluteal fibrosis }\end{array}$ & $\begin{array}{l}\text { Prevention (injection } \\
\text { and treatment) }\end{array}$ & $\begin{array}{l}\text { HIC } \\
\text { medical } \\
\text { student }\end{array}$ & $\begin{array}{l}\text { HIC/LMICs } \\
\text { orthopedic } \\
\text { surgeons }\end{array}$ \\
\hline 2016 & $\begin{array}{l}\text { Osteomyelitis/club-foot } \\
\text { research }\end{array}$ & Collaborative projects & $\begin{array}{l}\text { High burden of } \\
\text { osteomyelitis and } \\
\text { club-foot } \\
\text { Lessons of training }\end{array}$ & $\begin{array}{l}\text { Training } \\
\text { programs/courses } \\
\text { Club-foot lessons for } \\
\text { scale-up }\end{array}$ & $\begin{array}{l}\mathrm{HIC} / \mathrm{LMIC} \\
\text { trainees }\end{array}$ & $\begin{array}{l}\text { HIC/LMIC } \\
\text { orthopedic } \\
\text { surgeons }\end{array}$ \\
\hline 2016 & $\begin{array}{l}\text { Prevalence, burden and } \\
\text { access to care of } \\
\text { pediatric hernias }\end{array}$ & PhD project & $\begin{array}{l}\text { Burden and } \\
\text { epidemiology of } \\
\text { inguinal hernias }\end{array}$ & $\begin{array}{l}\text { Need for detection } \\
\text { and treatment }\end{array}$ & $\begin{array}{l}\text { LMIC } \\
\text { general } \\
\text { surgeon }\end{array}$ & $\begin{array}{l}\text { LMIC general } \\
\text { surgeon }\end{array}$ \\
\hline 2016 & $\begin{array}{l}\text { Barriers/Facilitators of } \\
\text { Access to Surgical } \\
\text { Care }\end{array}$ & Final thesis & $\begin{array}{l}\text { Substantial barriers to } \\
\text { surgical access }\end{array}$ & $\begin{array}{l}\text { Implementation of } \\
\text { programs to } \\
\text { improve access }\end{array}$ & $\begin{array}{l}\text { LMIC } \\
\quad \text { trainee }\end{array}$ & $\begin{array}{l}\text { LMIC general } \\
\text { surgeon }\end{array}$ \\
\hline 2016 & $\begin{array}{l}\text { Intestinal Atresia } \\
\text { Review }\end{array}$ & Manuscript & $\begin{array}{l}50 \% \text { mortality and } \\
\text { median presentation at } \\
7 \text { days old }\end{array}$ & $\begin{array}{l}\text { Early detection } \\
\text { Alternatives for } \\
\text { high-risk patients }\end{array}$ & HIC trainee & $\begin{array}{l}\text { LMIC pediatric } \\
\text { surgeon }\end{array}$ \\
\hline 2017 & $\begin{array}{l}\text { Understanding the } \\
\text { journey to care for } \\
\text { Ugandan children with } \\
\text { rare surgical diseases }\end{array}$ & $\begin{array}{l}\text { Oral presentation and } \\
\text { abstract publication }\end{array}$ & $\begin{array}{l}\text { Transport and financial } \\
\text { constraints are critical } \\
\text { High incidence of ARM } \\
\text { and Hirschsprung's } \\
\text { disease }\end{array}$ & $\begin{array}{l}\text { Capacity building of } \\
\text { health workforce } \\
\text { More effective } \\
\text { strategies for } \\
\text { financial protection }\end{array}$ & $\begin{array}{l}\text { HIC } \\
\text { Medical } \\
\text { Student }\end{array}$ & $\begin{array}{l}\text { LMIC pediatric } \\
\text { surgeon }\end{array}$ \\
\hline 2017 & Management of diabetes & Oral presentation & $\begin{array}{l}\text { Education seminars } \\
\text { effective at knowledge } \\
\text { translation }\end{array}$ & $\begin{array}{l}\text { Maintain education } \\
\text { outreach for } \\
\text { diabetes } \\
\text { management }\end{array}$ & $\begin{array}{l}\text { HIC } \\
\text { student }\end{array}$ & $\begin{array}{l}\text { LMIC pediatric } \\
\text { surgeon }\end{array}$ \\
\hline 2017 & $\begin{array}{c}\text { Pediatric surgery } \\
\text { epidemiology }\end{array}$ & National presentation & $\begin{array}{l}\text { High excess mortality } \\
\text { for selected diseases } \\
\text { Limited human } \\
\text { resources }\end{array}$ & $\begin{array}{l}\text { Increase capacity } \\
\text { Monitor outcomes }\end{array}$ & $\begin{array}{l}\text { HICLMIC } \\
\text { trainee }\end{array}$ & $\begin{array}{l}\text { HIC/LMIC } \\
\text { pediatric } \\
\text { surgeon }\end{array}$ \\
\hline 2017 & $\begin{array}{l}\text { Cost-effectiveness of } \\
\text { pediatric surgery } \\
\text { operating room }\end{array}$ & National presentation & $\begin{array}{l}\text { Favorable cost- } \\
\text { effectiveness and } \\
\text { economic benefit }\end{array}$ & $\begin{array}{l}\text { Scale-up investment } \\
\text { and monitor } \\
\text { outcomes }\end{array}$ & HIC trainee & $\begin{array}{l}\text { HIC/LMIC } \\
\text { pediatric } \\
\text { surgeon }\end{array}$ \\
\hline 2017 & $\begin{array}{l}\text { Out of pocket } \\
\text { expenditure for } \\
\text { pediatric surgery }\end{array}$ & National presentation & $\begin{array}{l}\text { Up to } 1 / 3 \text { of families will } \\
\text { incur catastrophic } \\
\text { health expenditure }\end{array}$ & $\begin{array}{l}\text { Improved financial } \\
\text { protection for } \\
\text { families }\end{array}$ & $\begin{array}{l}\text { HIC } \\
\text { medical } \\
\text { student }\end{array}$ & $\begin{array}{l}\text { HIC/LMIC } \\
\text { pediatric } \\
\text { surgeon }\end{array}$ \\
\hline 2017 & $\begin{array}{l}\text { Burden of surgical } \\
\text { infections on operative } \\
\text { volume }\end{array}$ & National presentation & $\begin{array}{l}\text { Substantial burden of } \\
\text { surgical infections, } \\
\text { often due to late } \\
\text { presentation }\end{array}$ & $\begin{array}{l}\text { Early diagnosis and } \\
\text { treatment }\end{array}$ & HIC trainee & $\begin{array}{l}\text { HIC/LMIC } \\
\text { pediatric } \\
\text { surgeon }\end{array}$ \\
\hline 2017 & $\begin{array}{l}\text { Pediatric surgical } \\
\text { stakeholder's meeting: } \\
\text { a way forward for } \\
\text { global collaborations }\end{array}$ & $\begin{array}{l}\text { International } \\
\text { presentation (World } \\
\text { Congress of } \\
\text { Surgery, Basel, } \\
\text { Switzerland) }\end{array}$ & $\begin{array}{l}\text { Local stakeholder's } \\
\text { meetings and priority } \\
\text { setting can be useful }\end{array}$ & $\begin{array}{l}\text { Follow-up in } \\
\text { thematic areas and } \\
\text { assess progress }\end{array}$ & $\begin{array}{l}\text { LMIC } \\
\text { pediatric } \\
\text { surgeon }\end{array}$ & $\begin{array}{l}\text { LMIC pediatric } \\
\text { surgeon }\end{array}$ \\
\hline
\end{tabular}


Table 4 continued

\begin{tabular}{|c|c|c|c|c|c|c|}
\hline Year & Project theme & Output & Main findings & Action items & $\begin{array}{l}\text { Presenting } \\
\text { author }\end{array}$ & Senior author \\
\hline 2017 & $\begin{array}{l}\text { Trachea-esophageal } \\
\text { fistula and esophageal } \\
\text { atresia: a 5-year } \\
\text { experience }\end{array}$ & $\begin{array}{l}\text { National presentation } \\
\text { (Kampala, Uganda) }\end{array}$ & $\begin{array}{l}\text { Feasibility of repair in } \\
\text { LMIC } \\
\text { Environment and high } \\
\text { mortality/morbidity }\end{array}$ & $\begin{array}{l}\text { Critical care capacity } \\
\text { building }\end{array}$ & $\begin{array}{l}\text { LMIC } \\
\text { pediatric } \\
\text { surgeon }\end{array}$ & $\begin{array}{l}\text { LMIC pediatric } \\
\text { surgeon }\end{array}$ \\
\hline 2017 & $\begin{array}{l}\text { Challenges and } \\
\text { opportunities for } \\
\text { pediatric surgery in } \\
\text { Uganda }\end{array}$ & $\begin{array}{l}\text { National presentation } \\
\text { (USA) }\end{array}$ & $\begin{array}{l}\text { Local initiatives to } \\
\text { strengthen capacity }\end{array}$ & $\begin{array}{l}\text { Growth of } \\
\text { international } \\
\text { collaborations to } \\
\text { support local } \\
\text { priorities }\end{array}$ & $\begin{array}{l}\text { LMIC } \\
\quad \text { pediatric } \\
\text { surgeon }\end{array}$ & $\begin{array}{l}\text { LMIC pediatric } \\
\text { surgeon }\end{array}$ \\
\hline 2018 & $\begin{array}{l}\text { Burden of emergency } \\
\text { procedures in pediatric } \\
\text { surgery on operative } \\
\text { volume }\end{array}$ & National presentation & $\begin{array}{l}\text { High burden of } \\
\text { emergency } \\
\text { procedures, impact on } \\
\text { wait lists, possible } \\
\text { new metrics }\end{array}$ & $\begin{array}{l}\text { Increase OR and } \\
\text { human resource } \\
\text { capacity } \\
\text { Monitor impact }\end{array}$ & HIC trainee & $\begin{array}{l}\text { LMIC/HIC } \\
\text { pediatric } \\
\text { surgeon }\end{array}$ \\
\hline 2018 & $\begin{array}{l}\text { SAFE anesthesia course } \\
\text { in Uganda }\end{array}$ & $\begin{array}{l}\text { International } \\
\text { presentation }\end{array}$ & $\begin{array}{l}\text { Feasibility and scale-up } \\
\text { of SAFE course }\end{array}$ & $\begin{array}{l}\text { Continue to scale up } \\
\text { and monitor } \\
\text { impact }\end{array}$ & - & $\begin{array}{l}\text { LMIC pediatric } \\
\text { anesthesiologist }\end{array}$ \\
\hline 2018 & $\begin{array}{l}\text { Congenital anomaly } \\
\text { identification }\end{array}$ & $\begin{array}{l}\text { Medical student } \\
\text { project }\end{array}$ & $\begin{array}{l}\text { Support for educational } \\
\text { programs for front line } \\
\text { health workers and } \\
\text { birth personnel }\end{array}$ & $\begin{array}{l}\text { Refine existing tools } \\
\text { for anomaly } \\
\text { identification and } \\
\text { pilot program }\end{array}$ & $\begin{array}{l}\text { HIC } \\
\text { student }\end{array}$ & $\begin{array}{l}\text { HIC/LMIC } \\
\text { pediatric } \\
\text { surgeon }\end{array}$ \\
\hline 2018 & $\begin{array}{c}\text { Factors affecting } \\
\text { immunization }\end{array}$ & Oral presentation & $\begin{array}{l}\text { Miscommunication and } \\
\text { variable record } \\
\text { keeping affect } \\
\text { immunization practice }\end{array}$ & $\begin{array}{l}\text { Implement standard } \\
\text { practice for } \\
\text { immunization } \\
\text { records } \\
\text { Increase educational } \\
\text { outreach regarding } \\
\text { immunization }\end{array}$ & $\begin{array}{l}\mathrm{HIC} \\
\text { student }\end{array}$ & $\begin{array}{l}\text { LMIC pediatric } \\
\text { surgeon }\end{array}$ \\
\hline 2018 & $\begin{array}{l}\text { Quality of life with } \\
\text { stoma }\end{array}$ & $\begin{array}{l}\text { Medical student } \\
\text { project }\end{array}$ & $\begin{array}{l}\text { Substantial burden of } \\
\text { ostomy and cost for } \\
\text { families }\end{array}$ & $\begin{array}{l}\text { Need for improved } \\
\text { counseling with } \\
\text { educational } \\
\text { materials for } \\
\text { families }\end{array}$ & $\begin{array}{l}\text { HIC } \\
\text { student }\end{array}$ & $\begin{array}{l}\text { HIC/LMIC } \\
\text { pediatric } \\
\text { surgeon }\end{array}$ \\
\hline 2018 & $\begin{array}{l}\text { Evaluation of the } \\
\text { Nutritional Status of } \\
\text { Ugandan Pediatric } \\
\text { Patients }\end{array}$ & $\begin{array}{l}\text { Oral presentation and } \\
\text { poster }\end{array}$ & $\begin{array}{l}25 \% \text { of pediatric patients } \\
\text { severely stunted, } \\
\text { severe wasting in } 20 \%\end{array}$ & $\begin{array}{l}\text { Undernutrition } \\
\text { common } \\
\text { Greater resources to } \\
\text { support nutrition } \\
\text { program }\end{array}$ & $\begin{array}{l}\text { HIC } \\
\text { student }\end{array}$ & $\begin{array}{l}\text { HIC and LMIC } \\
\text { pediatric } \\
\text { surgeon }\end{array}$ \\
\hline 2018 & $\begin{array}{l}\text { Medical student interest } \\
\text { in surgery }\end{array}$ & $\begin{array}{l}\text { International } \\
\text { presentation }\end{array}$ & $\begin{array}{l}\text { Majority of students } \\
\text { interested in infectious } \\
\text { disease } \\
\text { High rates of intent to } \\
\text { migrate }\end{array}$ & $\begin{array}{l}\text { Improve exposure to } \\
\text { surgery and } \\
\text { perception of } \\
\text { surgical careers }\end{array}$ & $\begin{array}{l}\text { LMIC } \\
\text { pediatric } \\
\text { surgeon }\end{array}$ & $\begin{array}{l}\text { HIC/LMIC } \\
\text { pediatric } \\
\text { surgeon }\end{array}$ \\
\hline 2018 & Postnatal care & Oral presentation & $\begin{array}{l}\text { Infant mortality rate } 5 \% \\
50 \% \text { staff unaware of } \\
\text { WHO guidelines }\end{array}$ & $\begin{array}{l}\text { Education seminars } \\
\text { and resource } \\
\text { allocation }\end{array}$ & $\begin{array}{l}\text { HIC } \\
\text { student }\end{array}$ & $\begin{array}{l}\text { LMIC pediatric } \\
\text { surgeon }\end{array}$ \\
\hline 2018 & $\begin{array}{l}\text { Impact of a pediatric } \\
\text { surgery unit }\end{array}$ & $\begin{array}{l}\text { International } \\
\text { presentation }\end{array}$ & $\begin{array}{c}\text { Substantial impact of } \\
\text { developing a unit }\end{array}$ & $\begin{array}{l}\text { Scale-up and build } \\
\text { capacity }\end{array}$ & $\begin{array}{l}\text { LMIC } \\
\text { trainee }\end{array}$ & $\begin{array}{l}\text { LMIC pediatric } \\
\text { surgeon }\end{array}$ \\
\hline 2018 & $\begin{array}{l}\text { Abdominal trauma } \\
\text { outcomes }\end{array}$ & Oral presentation & $\begin{array}{l}\text { High rate of negative } \\
\text { laparotomy in trauma }\end{array}$ & $\begin{array}{l}\text { Improve imaging } \\
\text { capacity } \\
\text { Develop injury } \\
\text { prevention } \\
\text { campaign }\end{array}$ & $\begin{array}{l}\text { HIC } \\
\text { student }\end{array}$ & $\begin{array}{l}\text { LMIC pediatric } \\
\text { surgeon }\end{array}$ \\
\hline
\end{tabular}


Table 4 continued

\begin{tabular}{|c|c|c|c|c|c|c|}
\hline Year & Project theme & Output & Main findings & Action items & $\begin{array}{l}\text { Presenting } \\
\text { author }\end{array}$ & Senior author \\
\hline 2018 & $\begin{array}{l}\text { Pediatric trauma patients } \\
\text { in Mbarara }\end{array}$ & $\begin{array}{l}\text { International } \\
\text { presentations }\end{array}$ & $\begin{array}{l}\text { Substantial burden of } \\
\text { injuries in children }\end{array}$ & $\begin{array}{l}\text { Improved } \\
\text { surveillance and } \\
\text { trauma care }\end{array}$ & $\begin{array}{l}\text { LMIC } \\
\text { pediatric } \\
\text { surgeon, } \\
\text { HIC } \\
\text { trainee }\end{array}$ & $\begin{array}{l}\text { HIC pediatric } \\
\text { surgeon }\end{array}$ \\
\hline
\end{tabular}

HIC high-income countries, LMIC low- and middle-income countries, PhD Doctor of Philosophy, SAFE Safer Anaesthesia from Education, USA United States of America

also continues to be a focus on interventions at the national referral hospital compared with rural hospitals. Development of a national referral service within the country including specialty or niche hospitals is needed and ultimately requires closer collaboration between institutions addressing children's surgery delivery and the Ministry of Health.

\section{Next steps}

Children's surgical capacity is increasing in Uganda, in part due to aligning stakeholders investing in infrastructure and human resources. At the first pediatric operating theater in Naguru, a Ugandan team of two pediatric surgeons, one pediatric anesthesiologist, two pediatric surgery fellows and multiple general surgery residents perform complex elective cases daily. Similar teams of orthopedic and plastic surgery specialists are trained in CoRSU. The ultimate goal will be to develop a sufficient number of children's surgical specialties in Uganda to make international training programs unnecessary. Continued alignment of like-minded organizations that invest in parallel and complementary themes is needed. Future aims include increased training for medical officers, general surgeons and anesthesia providers at rural hospitals, increased fellowship training programs for pediatric surgical subspecialties and more locally led research to inform practice and policy.

Continued advocacy for children's surgery at the Ministry of Health is required, including integration of children's surgery into the National Health Plan. As children's surgery crosscuts both Maternal and Child Health Policy and National Surgical, Obstetrics and Anesthesia Plans, children's surgery should be integrated into both of these agendas. Ongoing assessment of children's surgical volume, workforce and access will be needed, although no clear standards currently exist in LMICs. A recent review of surgical output highlighted the deficiency compared to global standards but did not include data on children [31].

\section{Public policy recommendations}

Policy 1 A stakeholders' meeting of local champions and international partners can be an initial step to inventory children's surgery programs, to define local challenges and context-specific solutions and to establish a children's surgery network. The network can set short- and longer-term goals based on local priorities, can grow over time and should cross-clinical disciplines.

Policy 2 Policies to inform service delivery must be implemented through the health system, including specialty or niche hospitals, and require assessment of resources at all levels of the healthcare system. Children's surgery teams at the national, regional and district levels can catalyze the progress. Rural Outreach Camps from both local children's surgery groups and international clinical partners must be centrally coordinated and standardized.

Policy 3 Children's surgery, anesthesia and perioperative care should be integrated in the development of national health policies and adapted to the local context.

\section{Conclusion}

The unification of stakeholders across clinical disciplines and institutional partnerships has increased children's surgical capacity in Uganda in key areas of training, infrastructure and service delivery. Expansion of capacity and evolution of multistakeholder engagement have created new dimensions of opportunities and challenges. Ultimately, coordination, shared decision making and distributed leadership are required to develop sustainable children's surgery in Uganda. This is dependent on collaboration of stakeholders at all levels of the health system. 
Acknowledgements The authors would like to thank all the individuals who participated in the stakeholders' meeting in 2015. We would also like to thank all the individuals who have assisted on the projects listed in this manuscript and who have endeavored to increase children's surgery and anesthesia capacity in Uganda over the last 3 years.

\section{Compliance with ethical standards}

Conflicts of interest The authors declare that they have no conflicts of interest.

\section{Appendix: Topics for pediatric surgery emergencies workshop for general surgeons}

\section{Surgical management of children}

Anesthesia and analgesia

Fluid management and blood transfusion

Tubes, lines and vascular access

\section{Neonatal emergencies and congenital anomalies}

Necrotizing enterocolitis

Gastroschisis and omphalocele

Neonatal intestinal obstruction

Hypertrophic pyloric stenosis

Hirschsprung's disease and constipation

Anorectal malformations

Esophageal atresia

\section{Intestinal emergencies, bone and soft tissue infections}

Appendicitis

Salmonella (typhoid)-associated perforation

Intussusception

Obstructed strangulated hernia

Rectal prolapse

Necrotizing fasciitis and pyomyositis

Acute and chronic osteomyelitis

\section{Urologic emergencies}

Acute scrotum

Febrile urinary tract infections

Phimosis/paraphimosis

Urinary retention

\section{Trauma}

Fractures
Burns
General pediatric trauma

\section{References}

1. Mock CN et al (2015) Essential surgery: key messages from disease control priorities, 3rd edition. Lancet 385(9983): 2209-2219

2. Meara JG et al (2015) Global surgery 2030: evidence and solutions for achieving health, welfare, and economic development. Lancet 386(9993):569-624

3. Farmer DL, Bickler SW (2016) Preface. Semin Pediatr Surg 25(1):1-2

4. Ozgediz D et al (2016) Pediatric surgery as an essential component of global child health. Semin Pediatr Surg 25(1):3-9

5. Butler MW et al (2015) The Global Paediatric Surgery Network: a model of subspecialty collaboration within global surgery. World J Surg 39(2):335-342. https://doi.org/10.1007/s00268014-2843-1

6. Goodman LF et al (2018) The global initiative for children's surgery: optimal resources for improving care. Eur J Pediatr Surg 28(1):51-59

7. Sonderman KA, Citron I, Meara JG (2018) National surgical, obstetric, and anesthesia planning in the context of global surgery: the way forward. JAMA Surg 153(10):959-960

8. Mukhopadhyay S et al (2017) Implementing World Health Assembly Resolution 68.15: national surgical, obstetric, and anesthesia strategic plan development-the Zambian experience. Bull Am Coll Surg 102(6):28-35

9. Mallapudi B et al (2018) An estimate of the number of children and adolescents worldwide without access to surgical and anesthesia care. Bull World Health Organ. Accepted Manuscript

10. Haider A et al (2017) Development of a unifying target and consensus indicators for global surgical systems strengthening: proposed by the global alliance for surgery, obstetric, trauma, and anaesthesia care (the G4 alliance). World J Surg 41(10):2426-2434. https://doi.org/10.1007/s00268-017-4028-1

11. Lipnick M et al (2013) Surgery and anesthesia capacity-building in resource-poor settings: description of an ongoing academic partnership in Uganda. World J Surg 37(3):488-497. https://doi. org/10.1007/s00268-012-1848-x

12. Sileshi B et al (2017) Monitoring anesthesia care delivery and perioperative mortality in Kenya utilizing a provider-driven novel data collection tool. Anesthesiology 127(2):250-271

13. Elzomor $\mathrm{H}$ et al (2017) A multidisciplinary approach to improving the care and outcomes of patients with retinoblastoma at a pediatric cancer hospital in Egypt. Ophthalmic Genet 38(4):345-351

14. Ekenze SO et al (2017) Neonatal surgery in a developing country: outcome of co-ordinated interdisciplinary collaboration. J Paediatr Child Health 53(10):976-980

15. Kiragu AW et al (2018) Pediatric trauma care in low resource settings: challenges, opportunities, and solutions. Front Pediatr 6:155

16. Penny N et al (2007) Community-based rehabilitation and orthopaedic surgery for children with motor impairment in an African context. Disabil Rehabil 29(11-12):839-843

17. Pirani S et al (2009) Towards effective Ponseti clubfoot care: the Uganda Sustainable Clubfoot Care Project. Clin Orthop Relat Res 467(5):1154-1163

18. Ameh EA, Seyi-Olajide JO, Sholadoye TT (2015) Neonatal surgical care: a review of the burden, progress and challenges in sub-Saharan Africa. Paediatr Int Child Health 35(3):243-251

19. Butler EK et al (2016) Quantifying the pediatric surgical need in Uganda: results of a nationwide cross-sectional, household survey. Pediatr Surg Int 32(11):1075-1085

20. Butler EK et al (2017) Epidemiology of pediatric surgical needs in low-income countries. PLoS ONE 12(3):e0170968 
21. Walker IA et al (2010) Paediatric surgery and anaesthesia in south-western Uganda: a cross-sectional survey. Bull World Health Organ 88(12):897-906

22. Linden AF et al (2012) Challenges of surgery in developing countries: a survey of surgical and anesthesia capacity in Uganda's public hospitals. World J Surg 36(5):1056-1065. https://doi. org/10.1007/s00268-012-1482-7

23. Krishnaswami S, Nwomeh BC, Ameh EA (2016) The pediatric surgery workforce in low- and middle-income countries: problems and priorities. Semin Pediatr Surg 25(1):32-42

24. Elhalaby EA et al (2012) Training and practice of pediatric surgery in Africa: past, present, and future. Semin Pediatr Surg 21(2):103-110

25. Chirdan LB et al (2010) Challenges of training and delivery of pediatric surgical services in Africa. J Pediatr Surg 45(3): 610-618

26. Everybody's business-strengthening health systems to improve health outcomes: WHO's framework for action (2007) World Health Organization, Geneva. http://www.who.int/healthsystems/ strategy/everybodys_business.pdf. Accessed 20 August 2018

27. Frank JR, Langer B (2003) Collaboration, communication, management, and advocacy: teaching surgeons new skills through the CanMEDS Project. World J Surg 27(8):972-978; discussion 978. https://doi.org/10.1007/s00268-003-7102-9
28. Dewan MC et al (2018) Global neurosurgery: the current capacity and deficit in the provision of essential neurosurgical care. Executive Summary of the Global Neurosurgery Initiative at the Program in Global Surgery and Social Change. J Neurosurg 27:1-10

29. Alves K et al (2018) Paediatric musculoskeletal disease in Kumi District, Uganda: a cross-sectional survey. Int Orthop 42(8): 1967-1973

30. Health services development. The WHO Health Systems Framework. World Health Organization, Geneva. http://www. wpro.who.int/health_services/health_systems_framework/en/. Accessed 20 August 2018

31. Albutt $\mathrm{K}$ et al (2018) Access to safe, timely, and affordable surgical care in Uganda: a stratified randomized evaluation of nationwide public sector surgical capacity and core surgical indicators. World J Surg 42(8):2303-2313. https://doi.org/10. 1007/s00268-018-4485-1

Publisher's Note Springer Nature remains neutral with regard to jurisdictional claims in published maps and institutional affiliations. 